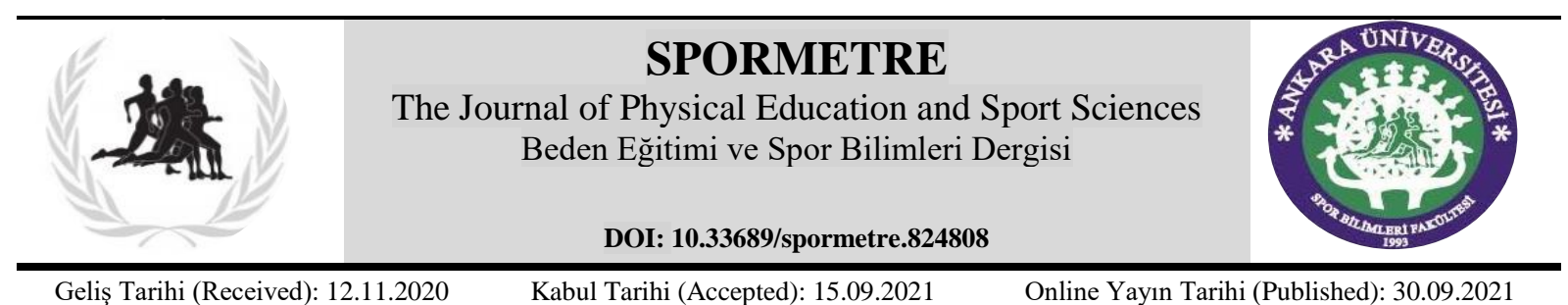

Geliş Tarihi (Received): 12.11.2020

Kabul Tarihi (Accepted): 15.09.2021

Online Yayın Tarihi (Published): 30.09.2021

\title{
PHYSICAL EDUCATION TEACHER EDUCATION IN TURKEY: A VISION FORWARD
}

\author{
Günay ŞEN ${ }^{1 * \mathbb{D}}$, Aaron BEİGHLE $^{1}$ (D) Nimet Haşıl KORKMAZ $^{2}$ (D) \\ ${ }^{1}$ University of Kentucky, College of Education, Kinesiology and Health Promotion Department, LEXINGTON \\ ${ }^{2}$ Uludağ Üniversitesi, Spor Bilimleri Fakültesi, Beden Eğitimi ve Spor Öğretmenliği Bölümü, BURSA
}

\begin{abstract}
Physical education in Turkey has a rich tradition evolving with the changing needs of the country for about 200 years. Much of the evolution has been a product of reflection on the history of physical education and an analysis of the current status of physical education. By examining these areas, pioneers of physical education in Turkey have been able to lead efforts through an ever-changing landscape of societal, personal, and educational needs of students. Considering the developing technological possibilities and the requirements of the age, it is essential to develop educational practices with innovative understanding in the field of physical education and teacher education programs today. The purpose of this paper is to provide a brief contextual overview of the history of physical education in Turkey, including teacher preparation as well as an overview of the current status of the field in schools. Building on this information, a vision forward for physical education teacher preparation will be provided leveraging the deep traditions of physical education planted in Turkey generations ago. In this context, the responsibilities of universities and other stakeholders in order to improve the physical education teacher education program will be explained with some examples and also recommendations will be provided.
\end{abstract}

Keywords: Physical education, teacher education, sport

\section{TÜRKIYY'DE BEDEN EĞITIMII ÖĞRETMENI YETISTTİRME PROGRAMI: GELECEĞE DÖNÜK BİR VIZYON}

Öz: Türkiye'de beden eğitimi, ülkenin değişen ihtiyaçlarıyla gelişen yaklaşık 200 yıllık zengin bir geleneğe sahiptir. Beden eğitimi fikrinin ortaya çıktığı ilk günlerden günümüze kadar geçirdiği evrimin çoğu, beden eğitimi tarihi üzerine düşüncelerin ve beden eğitiminin mevcut durumunun analizinin bir ürünü olmuştur. Bu tarihsel gelişmelerden yola çıkarak, Türkiye'deki beden eğitiminin öncüleri, öğrencilerin sürekli değişen toplumsal, kişisel ve eğitimsel ihtiyaçlarıyla ilgili çalışmalara öncülük etmişlerdir. Gelişen teknolojik olanaklar ve çağın gereklilikleri göz önüne alındığında, günümüzde de beden eğitimi alanında ve ö̆gretmen yetiştirme programlarında yenilikçi anlayışa sahip eğitim uygulamalarının geliştirilmesi zaruridir. Bu makalenin amacı, öğretmen yetiştirme programları ve beden eğitiminin okullardaki mevcut durumuna genel bir bakış da dahil olmak üzere, Türkiye'de beden eğitiminin tarihsel gelişimine kısa bir genel bakış sağlamaktır. Bu bilgilerden yola çıkarak, Türkiye'de nesiller önce ekilen derin beden eğitimi geleneklerinden yararlanılarak, beden eğitimi öğretmenlerinin hazırlanması için ileriye dönük bir vizyon sağlanmaya çalışılacaktır. Bu bağlamda, beden eğitimi yetiştirme programının iyileştirilmesi adına üniversitelere ve diğer paydaşlara düşen sorumluluklar bazı örnekler ve tavsiyeler ile açıklanacaktır.

Anahtar Kelimeler: Beden eğitimi, öğretmen yetiştirme, spor 


\section{INTRODUCTION}

About 200 years ago, physical education has been adopted into education systems with the goal of military needs and targets in many countries as well as in Turkey. In this process, physical education understanding in Turkey developed through different stages and gained its traditional structure. During these stages, many pioneering characters were serving the field, and they made great contributions to the progress of the field with their ideas and applications. Originally designed to serve military goals, physical education later evolved to serve students' physical, social, and psychological development. Undoubtedly, the most important building blocks of this development were physical education teachers. With the change in understanding of education and technological innovations in our age, teacher training programs have become more important than ever. In the literature review, the importance of designing physical education programs in accordance with today's requirements becomes evident. The purpose of this article is to provide a brief contextual overview of the history of physical education in Turkey, including an overview of the current status of PE in schools, and the current state and applications of teacher education programs. With this perspective, suggestions for the vision forward will be presented for the development of physical education teacher education programs.

During a time of great innovation throughout Europe, in 1839 the Ottoman Empire began to carry out physical activities under the name of 'gymnastics' in military schools (Mehmed Esad, 1315, as cited in Ozcakir, 2015). Physical Education in Turkey started to be taught in public schools for the first time during the Ottoman period in 1868. Specifically, physical education was first taught in a public school in Galatasaray High School, where French high schools educational programs were applied (Mehmed Esad, 1315, as cited in Ozcakir, 2015). As in other countries in the world, over time a set of norms and regulations for the implementation of physical education classes in Turkey have been established.

Much of the foundational work in physical education in Turkey was lead by Selim Sirri Tarcan. After completing his education in Sweden in 1911, Tarcan worked as a physical education teacher in the Military Forces. Selim Sirri, began his activities related to sports in Turkey by establishing the first National Olympic Committee and thus became famous. In 1925, he was appointed to the Ministry of National Education as a physical education chief inspector (Araci, 2004). This task briefly gave him the title of the leader of the inspectors who supervised physical education teachers and had a say in the development and supervision of physical education in the country. As a result of his hard work, physical education was recognized in Turkey for providing students with knowledge, skills, and attitude. At that time, two views on physical education were dominant, the Amoros Gymnastics and the Swedish Gymnastics approach which Tarcan supported (Araci, 2004). Amoros, who had an important contribution to the birth of modern sport, was a military-based gymnast who opened his first gym in France (Ozcakir, 2015). In physical education, he aimed at military purposes as well as health. The Swedish gymnastics, founded by Pehr Henrik Ling, was a health-focused approach and was recognized for its natural medical values (Araci, 2004). The Swedish 'light gymnastics' used no apparatus, consisting of calisthenics and exercises. It was freer and less harsh than the German and Amoros system (Wanneberg, 2018). For many years this was a more appealing approach to physical education and thus has become the prevailing pedagogy in physical education.

\section{The Current Status of Physical Education in Turkey}

The Turkish Ministry of National Education (MoNE) is the governing body that determines what style of physical education will be offered to youth during school. Currently, physical 
education programs include the compulsory 'Physical Education and Game' course in elementary schools. The aim of 'Physical Education and Game' course in elementary school is to prepare students for the next level of education by developing fundamental movements, active and healthy living skills, concepts and strategies, and related life skills that they will use throughout their lives through play and physical activities (MoNE, 2018). This course is offered five hours per week in grades 1-3 and two hours in the 4th grade and it is conducted by the classroom teachers. The compulsory 'Physical Education and Sport' course in middle schools is two hours per week in 5th to 8th grades and is the continuation of the 'Physical Education and Game' course in elementary schools. Most importantly, these courses during these years of education are taught by appointed physical education teachers. As the aims of physical education lessons in these grades, it can be said that the development of preparatory game practices for sports branches between the 5th and 7th grades, and then the development of movement skills specific to different sports branches (football, volleyball, basketball, etc.) in the 8th grade. In addition to this course, there is a 2-hour elective course under the name of 'Sports and Physical Activities' in the middle school. Within this course, students receive intensive training for a semester on a sports branch decided by the teacher. In this course it is also suggested to use Sport Education Model to teach the different sport branches to students (Siedentop, 1984). The material of these courses are designed to teach the sport branch in the first semester and suggested to use Sport ed. Model for the second semester. In many different types of high schools (grades 9 and 12), Physical Education and Sport is 2 hours per week and is compulsory in some types of schools and elective for some others (MoNE, 2018).

Table 1. Current requirements of PE classes in Turkey ( $\mathrm{CT}=$ Classroom teacher, $\mathrm{PET}=$ Physical education teacher, Comp.= Compulsary, Elec. $=$ Elective)

Physical Education Program in Turkey (MoNE, 2018)

\begin{tabular}{|c|c|c|c|c|c|c|c|c|c|c|c|}
\hline \multicolumn{4}{|c|}{$\begin{array}{l}\text { Elementary School } \\
\text { Physical Education and Game }\end{array}$} & \multicolumn{4}{|c|}{$\begin{array}{l}\text { Middle School } \\
\text { Physical Education and Sport }\end{array}$} & \multicolumn{4}{|c|}{$\begin{array}{l}\text { High School } \\
\text { Physical Education and Sport }\end{array}$} \\
\hline Class & Hours & By & Status & Class & Hours & By & Status & Class & Hours & By & Status \\
\hline 1 & 5 & CT & Comp. & 5 & 2 & PET & Comp. & 9 & 2 & PET & Elec. \\
\hline 2 & 5 & CT & Comp. & 6 & 2 & PET & Comp. & 10 & 2 & PET & Elec. \\
\hline 3 & 5 & CT & Comp. & 7 & 2 & PET & Comp. & 11 & 2 & PET & Elec. \\
\hline 4 & 2 & CT & Comp. & 8 & 2 & PET & Comp. & 12 & 2 & PET & Elec. \\
\hline
\end{tabular}

According to the new secondary education system announced by MoNE, the number of compulsory courses will gradually decrease and the courses will mostly be in elective status effective for 2020-2021 education period. One of the courses to be elective is physical education. While this is a step backwards for the field, potentially it frees programs up to offer more student friendly offerings. Also, the new PETE program has changed by Higher Education Council of Turkey (HEC-YÖK) in 2017. The content of the courses taken by the students for a total of 8 semesters (4 years) consists of $33 \%$ vocational knowledge, $18 \%$ general culture, and $49 \%$ physical education field knowledge (YÖK, 2017). With this change, it was desired to focus on field-related education instead of sport-specific education. However, as the effects of this change will emerge in the long term, no data have been reached yet. 
As mentioned before, the PETE program is regulated by Higher Education Council (YÖK), while the curricula of the schools are regulated by the Ministry of National Education (MEB). This situation can create problems in terms of educational goals and field realities of both institutions. With the new physical education undergraduate program, in order to improve the expertise of teacher candidates and to increase their skills and knowledge in different fields, many elective courses have been added to the program in addition to the compulsory courses that have not changed much compared to the old program. While defending the view that this practice is a very positive progress on paper, up-to-date studies are needed to comment on the applicability of elective courses, the qualifications of instructors, whether there is a need for qualified instructors who are experts in their fields, and to what extent universities can integrate the aforementioned elective courses into their programs. The increase and quality applications of elective courses that serve the interests of individuals will undoubtedly expand the scope of the physical education teacher education program and increase its quality.

Teacher candidates face problems in their coursework due to the difference between the facilities and materials they have during their undergraduate education and the proficiency in the schools they are assigned to (Temiz \& Sivrikaya, 2021). In addition, according to the results of some studies, the inadequacy of general education and physical education-specific pedagogical training in undergraduate education, the difference between the undergraduate education curriculum and the curriculum of the schools affiliated to the Ministry of National Education create conflicts in terms of PETE and beyond (Sağın \& Karabulut, 2020; Temiz \& Sivrikaya, 2021). However, this problem is not unique to Turkey only. For example, in some states of the United States, elementary, middle, and high school physical education classes are not required, and therefore expectations from a physical education teacher may differ from what is taught in the PETE program.

Within lessons, it appears as though teachers continue to apply antiquated strategies not consistent with current thinking. Cicek \& Demirhan (2001) suggested that teachers apply older strategies and dated lessons during their physical education courses. In a study by Ince and Hunuk (2010), teachers' adoption and preference of teacher-centered physical education teaching styles suggest that teachers do not give up the old physical education practices that prioritize developing skills specific to sports, and do not absorb the content of the new curriculum. Unlike other developed countries, some physical education classes are still conducted with the military system by teachers who have earlier, traditional mentality in Turkey (Hasirci, 2012). Currently, scholars recommend student-centered educative pedagogy strategies rather than teacher-centered and command style methodologies (Goodyear \& Dudley, 2015). For example, the activities of lining-up students before and after each lesson can be shown as a traditional activity that strongly demonstrates the impact of military understanding in the field of physical education. Although not documented in a curriculum, it is known that physical education teachers often use these types of exercises at the beginning and the end of the lesson and also to ensure order and discipline during ceremonial times (Hasirci, 2012). While only one example, this example is presented to articulate the need for new practices and new teaching strategies as well as contemporary curricula in Turkey. Bozoglu and Gokturk (2016) found that once out of secondary school students report their physical education was not a joy. This is of particular concern and strong suggests a renewed emphasis on quality physical education in Turkey is warranted. Specifically, our goal is to provide some beneficial solutions to the Teacher Training Program in Turkey, particularly for the Physical Education/Teacher Education Program. 


\section{Physical Education Teacher Education in Turkey}

Before delving into a vision for PETE in Turkey a brief overview of the history of PETE in Turkey will provide context. As the field evolved and established itself in schools the next challenge became the training of qualified physical education teachers. With the efforts of Selim Sirri, construction of the first gymnasium hall began in 1926 in Istanbul. At the end of construction, a 'Physical Education Teacher Training Course' was established in 1927 (Araci,2004). Three Physical Education Teachers from Sweden were brought from abroad to train the teachers. These were, Inge Nerman (for girls), Rangar Johnson (for boys), and Suen Alexanderson (for Massage and Medical Gymnastics) (Tayga, 1990). Each period of the course lasted from 6 to 9 months and was used until the 1930s. The lessons offered by the course were as follows; theories and practice of physical education, physiology, anatomy, movement ability (motility), public health, theoretical and applied sports lessons (Ceyhan, 2004). In 1932, for the first time in the history of the Republic, the Department of Physical Education was established in Ankara under the name of Gazi Teacher Training School (Ceyhan, 2004). This program was the first to prepare physical education teachers to help fill the void of physical education teachers throughout Turkey. The first course program in historical records of Gazi Teacher Training School's syllabus included the courses; gymnastics, sports, games and folk dances, medical gymnastics and massages, exercises and seminars, pedagogy and public teaching methods, physical education theory, history of physical education, anatomy, physiology, sports health, organization and administration, foreign language, music, military service, and Turkish History of Turkish Revolution were taught for 3 years, 204 hours and six semesters (Guclu, 2001).

After the 1960s, the importance of physical education in human health and development was accepted by the society and accordingly, the departments of physical education in universities increased one by one. There are now 80 public and 13 private universities that have 'Physical Education/Sport Education Program' in Turkey (YÖK, 2020). Within the Faculty of Sport Sciences; physical education and sports teaching, coaching, sports management and recreation departments are mostly common, sports sciences, exercise and sports education for disabled people, and exercise and sports sciences departments are also available in some universities. Each year a total of nearly 4.000 physical education teacher candidates graduate from universities. The recruitment of teachers to public schools is made according to the results of a central examination called Public Personnel Selection Exam (KPSS), which is held every year. According to the results of the last 6 years' assignments, 540 people in 2021,711 people in 2020,845 people in 2019,673 people in 2018,744 people in 2017 , and 1261 people in 2016, a total of 4774 physical education teachers were appointed to public schools in Turkey (MEB, 2021). In other words, in this 6-year period, only 4774 of the 24.000 graduates of physical education departments were able to begin their duties as 'physical education teachers' after qualifying KPSS. Those who cannot get enough points to be appointed from the KPSS exam have to work with lower wages and more workloads in private schools or any other jobs that they were not educated for.

The most recent analysis of physical education teacher education program offerings in Turkey suggests programs provide in-depth knowledge associated with specific sports and activities, that is, students in these programs learn the skills, rules, and strategies requisite to teach these games (Dervent, Devrilmez, Ince \& Ward, 2020). Despite the transition from skill and sportspecific teaching method to teaching techniques and content knowledge method in the recently updated national PETE curriculum, this change shows that PETE students have not yet reached the desired level of content knowledge (Dervent et al., 2020). While exposure to sport-specific skills is important, it is our belief that the teaching practices needed to implement those skills 
supersedes these skills. That is, it is argued here that more and quality time be spent teaching future teachers teaching methodology during teacher preparation programs. The expectation would be that basic sport and movement specific content can be learned simultaneously and then built on throughout the teaching career.

\section{VISION FORWARD}

Turkey's education vision for 2023 support that "It should not be forgotten that every education system rises on the shoulders of teachers and none of them can exceed the quality of their teacher" (MoNE, 2018). As can be seen from here, teacher training programs and updating practices are vital in order to fulfill the requirements of the era and to implement educational systems. Most recently, Turkey has released a key document '2023 Education Vision' outlining future objectives of education. This is a very important breakthrough in terms of seeing the country ahead and advancing more firmly into the future. However, the document does not contain expressions and plans aimed at major changes in physical education and sports. Therefore, parallel targets can be determined by using 'Making Physical Education Dynamic and Inclusive for 2030' announced by OECD (2019). This document draws conclusions about how physical education programs change from country to country, the importance of sports and physical education and health outcomes, past, present and future statuses in physical and health education. By aligning these two visionary pieces, it is possible to see the role of physical education and ultimately physical education teacher education in a vision forward for PETE in Turkey.

In Turkey, the course curriculums of the universities are determined by the 'Higher Education Council' which is the central authority. However, while the university curriculum is determined by this institution, the primary-middle-high school's curriculum, objectives, outcomes and projects in the schools are determined by the Ministry of National Education (MoNE). Therefore, cooperation between these two institutions should be maximized for quality educators and quality education curriculums. In many European countries, institutions such as teacher academies, carry out supervision studies on the development of the field of education and the direction of this development (Jones, \& Green, 2015). These kinds of studies emphasize the importance of determining high standards and cooperation to achieve impactful teacher education.

We live in an age where communication and technological developments are at a high level. While some countries take correct and rapid steps in the field of education, some countries may be late in taking these steps. In this case, the most constructive and robust regulation is to examine the implementation methods of other countries in the field of education and adapt them according to the country's conditions, goals and standards. In this sense, examining the works of Hardman (2008), which analyzes physical education data in many countries around the world, and MacPhail, Tannehill, Avsar (2019), which conveys the application principles of physical education in European countries, will be very useful for creating future visions by the MoNE and other stakeholders in the field.

To build on the strong foundation Turkey has in physical education and the MoNE vision, while addressing the challenges that all education systems face, it is pivotal that a vision forward for preparing transformational future physical educators to be considered. Specifically, a vision that establishes strong teacher education programs that are essential components of the development of active and healthy youth throughout Turkey. We believe at the core of this process will be university teacher training programs. These programs provide the way forward 
and offer a source of sustainability in the future. To this end, the following visionary recommendations are made.

\section{University Coursework (Content)}

The physical education course content in Turkey emphasizes the importance of motor competence as well as active and healthy living. This can be accomplished by providing students with physical, emotional, mental, and social skills. This aligns with the role of physical education in providing skills, knowledge, and attitudes for lifelong physical activity. It follows that teacher preparation programs should prepare future physical educators to lead students on a journey of skill acquisition in these areas. However, it is important to emphasize 'lead' in the previous sessions. Simply having knowledge in the areas of skills, knowledge and attitudes does not enable a teacher to lead students on this journey. That is, knowing the technical skills of gymnastics, or the social benefits of physical activity alone does not make a successful physical education teacher. In fact, it could be argued that content knowledge is secondary to pedagogy skills. Without the pedagogical skills needed to lead students, the utility of the content knowledge is limited. Thus, it is not advocated that future teachers not be exposed to sports and physical skills, but rather be exposed to those skills as the backdrop of lessons emphasizing pedagogy best practices. Students should not only learn teaching strategies but also strategies for applying concepts associated with motivation, meaningfulness, biomechanics, exercise science, and other courses into their teaching.

To meet the needs of students who have technology as a native language, future PE teachers must learn to leverage this fluency in their preparation, during their lessons, and through their assessments. Entire textbooks and volumes of literature are dedicated to strategies using technology in physical education. The key to use technology in physical education is making sure the technology is being used to enhance the learning experience as opposed to being used for the sake of using technology. For instance, some teachers use a phone app to designate teams for a class; however, this process requires considerable time before the class to enter names and then takes time during class because of absences. A more efficient approach would have been getting students in partners and create teams by dividing all sets of partners to create two teams. The technology resources that can enhance instruction are endless with more being produced daily. Thus, a teacher who uses technology during physical education has a greater chance of connecting with a tech savvy population while enhancing their instruction. However, without being trained to integrate technology into physical education lessons, future PE teachers are less likely to implement this strategy (Gibbone, Rukavina, \& Silverman, 2010).

The contemporary role of physical educators in school is that of a physical activity leader (Beighle, Erwin, Castelli, Ernst, 2009). The role of the physical activity leader can be said to be to encourage school staff, students and their families to engage in physical activity, to integrate such activities into the academic curriculum, and to train these people to create opportunities to participate in the activities themselves (Heidorn \& Centeio, 2012). Some refer to the whole school approach to physical activity as a Comprehensive School Physical Activity Program (SHAPEAmerica, 2007), while others use 'Creating Active Schools' (Daly-Smith, Quarmby, Archbold, et al. 2020). In essence, this approach expands the reach of the physical education program and makes it a central part of the school culture. As Beighle and colleagues (2009) suggest, taking on this role requires intentional educational experiences for students during their training programs. For instance, experience observing and working during recess or in an afterschool program. Another example, is assisting a practicing teacher with a parent night in a school. These experiences better prepare students to take on the role of physical activity in schools. 
It is dually noted that the above ideas will be added to an already full academic schedule for university students. While anytime content is added to a curriculum, in this case a teacher training curriculum, decisions will have to be made on what to deemphasize and what to emphasize, some creativity and an open mindset can help this process. For example, the whole school physical activity approach can be taught throughout the program. During organization and administration type courses, content associated with marketing and politicking to expose the program can be taught. During activity courses, strategies for modifying activities for recess play can be used. As stated earlier, content from sport psychology can be integrated into skills courses to demonstrate how to make physical activity experiences meaningful. While not an exhaustive list, the above examples demonstrate strategies for integrating many new concepts into existing teacher training courses to ensure future teachers are prepared for the education world they will be teaching in.

\section{University Field Experiences}

While the courses taught on campus serve as the foundation for future teachers, their experiences in the schools are of equal importance. Future teachers must be in schools as future teachers to begin to understand the complexities and uniqueness of the school setting. These experiences also allow them to apply content learned on campus, in a real-world setting, with real students. And it allows them to interact with current teachers to learn and develop networks of colleagues they may have throughout their careers. It is our suggestion that field experiences be embedded into course work on campus. That is, learning experiences in the courses are built around field experiences. As stated earlier, this will require making decisions. However, it is believed that these experiences are so valuable, these cuts are necessary. For instance, in a traditional course that allows for 45 hours of student contact in the university classroom, that contact may be cut to 35 hours with 10 hours allocated for field experiences. Again, this time is not simply for students to observe physical education, but rather apply content learned in the course to the real world. Similar to students learning to dribble and shoot in soccer. They must be afforded the opportunity to apply those skills to fully learn them. Thus, is the case with teaching skills as well. Care must be taken to ensure the field experience placements are quality and are conveying similar messages to that taught in the classroom. This will be discussed further below.

The current PETE curriculum offers 2 semesters field experience classes in the $4^{\text {th }}$ year of undergraduate education. Students appoint on specific schools and in-service PE teachers for two terms teaching practice. This practice, which seems to be a good practice on paper, has important problems in itself. In addition, students who are in the last year of their education cannot provide the necessary benefit due to future anxiety, KPSS exam preparation, and lack of school experience. Namli and Temel (2019), in an interview study that they evaluated PETE program of Turkey, suggest that school experience and teaching practice lessons need a major revision and improvement to make these classes more coordinated and efficient. As mentioned earlier, we suggest that the time allocated for these courses should be increased and planned with a strong cooperation to be developed with schools, not only in the last year, but also from the first semester that students step into university. It may be more beneficial for the psychological and professional development of students to participate in teaching practices over time.

The culminating experience in an initial teacher training is the student teaching experience. In fact, it has been argued that the student teaching experience is the most important event in the preparation of teachers (REF). This is a time for future PE teachers to begin spreading their 
wings as teachers. The important component of this experience is the teacher in the school working with the teacher trainee, referred to here as the cooperating teacher. The cooperating teacher essentially takes the baton from the University faculty and leads the teacher trainee through the day to day teaching process. From duties before school, curriculum planning, faculty meetings, lunch, to other duties, lesson planning, and end of day tasks, future teachers learn what it means to be a teacher modeled by a passionate true professional. Future teachers learn to implement content and teaching strategies learned during the course work, they learn to modify as needed, how to apply assessment strategies and use these data for lesson or curricular changes. Students learn how to ask questions of students, get to know students, build relationships with students, making experiences meaningful, and how to motivate students. This may sound daunting, but teaching can be complex. The role of the university course work is to reduce this content into learnable chunks, teach students, and then provide students with the environment during student teaching to apply that content and teaching skills.

\section{University Collaboration}

Universities are state institutions that survive with state aid. These collaborative efforts can help both teachers and the University. As stated above, without schools and cooperating teachers, field experiences are not possible making the full potential of a PETE unachievable. Prusak and colleagues (2010) found that university collaboration with schools is foundational for teacher preparation and quality physical education in the schools. That is, university-school collaboration is synergistic in that both groups benefit. Universities work to provide contemporary, cutting edge professional development for physical educators. In turn, these physical educators work with university students, future PE teachers, to train quality physical educators. And this cycle can continue. This process allows universities to show teachers they truly care. Ozkara (2018) calls for the need for teachers to be appreciated and for them to feel appreciated. One way to do this is for universities to collaborate, conduct needs assessments, and then prepare teacher-centered professional development and assistance as provided. University faculty typically have more access to trends in the field. Why not extend this information to teachers to ultimately impact youth in schools?

Universities and schools can collaborate in other ways as well. According to newly announced Turkey's 2020 budget by the strategy and budget department (SBB), for the Ministry of National Education about 125 million TL ( $\$ 19$ million), for the Ministry of Youth and Sports approximately 18 million TL (\$2.5 million) was allocated (SBB, 2020). While the Ministry of National Education is responsible for the expenses of schools and teachers, the Ministry of Youth and Sports uses this budget for items such as improving sports awareness and habit, enabling students of all levels to do sports, increase sports participation, and sport facility constructions. These two ministries play a leading role in both sports investments and teacher recruitment. This appears to provide an excellent opportunity for schools, communities, and universities to collaborate to leverage their expertise for funding and the good of all youth. Although the "Health-related physical fitness report" project, which started to be implemented in 2016 with the partnership of the Ministry of National Education, Ministry of Health and the Ministry of Youth and Sports, is one of the most important examples of the cooperation we mentioned, this cooperation should continue to grow (MoNE, 2017).

Another important point is that in-service trainings (INSET) can be planned in a more professional way and with more teacher participation, by universities in the region. Ince et al. (2018) report that over the past 3 years, only 29 percent of physical education teachers participated in professional development activities in Turkey. Additionally, Hunuk et al. (2019) says that, physical education teachers who are new to the profession need the most help and 
mentorship in the first years of their profession to overcome the problems of transition from being a student to being a real teacher. Universities, which are teacher training institutions, should support these teachers with up-to-date trainings in the following periods. The winner of this collaboration will be the developing teachers and healthy generations growing up with quality, meaningful physical activity experiences.

\section{Research and Projects}

Collaboration can also be applied to research. Universities study to expand the body of knowledge in all areas, and physical education should be no different. Typically research in the area of physical education requires study in schools. However, this study is not always conveyed back to schools to positively impact their practice. A review of the research on physical education in Turkey reveals very few studies. This dearth of research provides an open book for physical educators to explore.

The importance of creating projects aiming quality physical education is tried to be integrated into their systems by some countries in the world. Universities and academicians are pioneers who should produce projects according to the conditions of the country in the light of developing science and approaches. For example, in the USA, 'Comprehensive School Physical Activity Program (CSPAP)' is planned by ShapeAmerica and aimed to create a framework for planning and organizing activities for children and adolescents to help them have at least 60 minutes physical activity each day (ShapeAmerica, 2007). Also, in Australia, The Australian Council for Health, Physical Education and Recreation (ACHPER)'s projects aimed that rather than focusing on traditional aspects of physical education, such as teaching how to do a particular sport, it focuses on a broader understanding of how to accurately convey physical activity and what it means for students (ACHPER, 2017). Turkey started to implement the 'Health Related Physical Fitness Report' in order to obtain and monitor students' health-related data in 2016 (MoNE, 2017). In this context, with the measurements made twice a year, the height, weight, flexibility and strength data of the students are added to the private online system and presented to the families. Singapore takes a different approach to obtain the results of the applied methods in physical education. They conduct a compulsory fitness test called 'NAPFA' every year for elementary and middle school students since 1982 (Veerendra, 2020). Although this practice seems problematic in terms of time and expenses, having data for the healthy development of students can serve the interests of the country. The basic and important point here is that countries should develop their own systems and projects according to their needs and expectations.

\section{CONCLUSION}

To sum up, in this article, changes in the Turkish physical education teacher education system that will better prepare pre-service teachers for their professions, such as cooperation between institutions in teacher education, providing course content for current needs, and adapting the right practices on paper to real life, regardless of the curriculum content, are discussed. Rather than problems such as financial insufficiencies, various curriculum applications, facility inadequacies, and the differences between the application models on the curricula and the applications in the field, we believe that, implementation of university's new PETE programs into the field accordance of the expectations of the profession and teachers, and adding more up-to-date and innovative approaches might be helpful to train more conscious physical education teachers in the future. Field experiences of pre-service teachers are as important as PETE program's content and quality. Universities play the biggest role in both establishing physical education curricula and cooperation with other government institutions to advance 
physical education in the country. As the field of physical education continues to build on its rich tradition in Turkey, teacher education programs will be an integral piece of the vision forward.

\section{REFERENCES}

Araci, H. (2004). Öğretmenler ve öğrenciler için okullarda beden ĕgitimi. Nobel.

Beighle, A., Erwin, H., Castelli, D., Ernst, M. (2009). Preparing physical educators for the role of physical activity director. Journal of Physical Education, Recreation \& Dance, 80(4), 24-29.

Bozoglu, O., Gokturk, S. (2016). What's Going on in Physical Education Classes in Turkey? An Insight into Student Attitude towards Physical Education, Curricular Issues and School Conditions. Journal of Education and Practice, 7(33), 156-165. https://eric.ed.gov/?id=EJ1122607

Ceyhan, E. (2004). Türk eğitim tarihi kronolojisi (pp.92). Ulusal Bellek Yayınları.

Cicek S., Demirhan G. (2001). Validating teacher competicies for Turkish physical education teacher. A national study using "Focus” Delphi Method. International Journal of Physical Education, 38(1), 35-42.

Daly-Smith, A., Quarmby, T., Archbold, V. S., Corrigan, N., Wilson, D., Resaland, G. K., Mckenna, J. et al. (2020). Using a multi-stakeholder experience-based design process to co-develop the Creating Active Schools Framework. International Journal of Behavioral Nutrition and Physical Activity, 17(13).

Dervent, F., Devrilmez, E., Ince, M. L., Ward, P. (2020). A national analysis of the content knowledge of Turkish physical education teacher education students. Physical Education and Sport Pedagogy, 25(6), 613-628. https://doi.org/10.1080/17408989.2020.1779682

Gibbone, A., Rukavina, P., \& Silverman, S. (2010). Technology integration in secondary physical education: Teachers attitudes and practice. Journal of Educational Technology Development and Exchange, 3(1), 27-42.

Goodyear, V., Dudley, D. (2015). “I'm a facilitator of learning!” understanding what teachers and students do within student-centered physical education models. Quest, 67(3), 274-289. 10.1080/00336297.2015.1051236

Guclu, M. (2001). Avrupa, Amerika Birleşik Devletleri, Çin ve Türkiye'de beden eğitimi ve sporun gelişimi. Milli Eğitimi Dergisi, 150, 33-38.

Hasirci, S. (2012). Physical education in Turkey. Journal of Physical Education \& Health, 1(2), 27-35.

Heidorn, B., Centeio, E. (2012). The director of physical activity and staff involvement. JOPERD, 83, 13-26.

Hunuk, D., Avsar, Z., Kupr, J., Gobbi, E. (2019). Inductions of physical education teachers in Europe. Journal of PhysicalEducation, 30(1), e-3066. http://periodicos.uem.br/ojs/index.php/RevEducFis/article/view/46528

Ince, M. L., Hunuk, D. (2010). Experienced physical education teachers' use and perceptions of teaching styles during the educational reform period. Education and Science, 35(157), 129-139.

Ince, M. L., Hunuk, D., Ozturk, M. A., Yanık, M., Savucu, Y. (2018). PE teacher professional development project needs analysis report. The Scientific and Technological Research Council of Turkey.

Jones, L., Green, K. (2015). Who teaches primary physical education? Change and transformation through the eyes of subject leaders. Sport, Education and Society, 22(6), 759-771. https://doi.org/10.1080/13573322.2015.1061987

MoNE (2017). Beden eğitimi ve spor öğretmenleri için sağlıkla ilgili fiziksel uygunluk karnesi uygulama rehberi. Retrieved July 15, 2021, from https://okulsagligi.meb.gov.tr/www/beden-egitimi-ve-spor-dersi-ogretmenlerine-verilecek-quotfiziksel-aktiviteuygunluk-karnesiquot-egitimi/icerik/47 
MoNE (2018). Beden eğitimi ve oyun dersi öğretim programı (1-4.Sınıflar). Milli Eğitim Bakanlığı Yayınları.

MoNE (2018). Beden eğitimi ve spor dersi öğretim programı (Ortaokul 5-8. Sınıflar). Milli Eğitim Bakanlığı Yayınlar1.

MoNE (2018). Ortaöğretim kurumları haftalık ders çizelgesi. Talim ve Terbiye Kurulu Başkanlığı. Milli Eğitim Bakanlığı Yayınları.

MoNE (2018). Turkey's 2023 Education Vision. Publications of the Ministry of National Education. Retrieved December 5, 2020, from http://2023vizyonu.meb.gov.tr/doc/2023_VIZYON_ENG.pdf

MoNE (2021). Öğretmen atama sonuçları. Retrieved July 15, 2021, from https://personel.meb.gov.tr/

Namli, A. K., Temel, C. (2019). Beden eğitimi ve spor öğretmenliği lisans programının değerlendirilmesi ve program önerisi. Milli Eğitim Dergisi, 48(1), 321-351.

OECD (2019). Making Physical Education Dynamic and Inclusive for 2030.

Ozcakir, S. (2015). Physical education teaching in Turkey 100 years ago and its current reflections. Hacettepe Journal of Sport Sciences, 26 (1), 18-25.

Ozkara, A. B. (2018). Physical education in EU schools and Turkey: A comparative study. Comparative Professional Pedagogy, 8(2), 101-106. https://doi.org/10.2478/rpp-2018-0026

Prusak, K. A., Pennington, T., Graser, S. V., Beighle, A. (2010). Systemic success in physical education: The East Valley Phenomenon. Journal of Teaching in Physical Education, 29(1), 85-106. https://doi.org/10.1123/jtpe.29.1.85

SBB (2020). Türkiye Cumhuriyeti Cumhurbaşkanlığı Strateji ve Bütçe Başkanlığı. Retrieved December 5, 2020 , from https://www.sbb.gov.tr/wp-content/uploads/2020/01/2020_vatandasinbutcerehberi.pdf

SHAPE America (2007). Comprehensive school physical activity programs: Helping all students log 60 minutes of physical activity each day. Reston.

Siedentop, D. (1994). Sport education: Quality PE through positive sport experiences. Human Kinetics.

Soyer, F. (2004). Osmanlı Devleti’nde (1839-1908 Tanzimat Dönemi) Beden eğitimi ve spor alanındaki kurumsal yapılanmalar ve okul programlarındaki yeri konusunda bir inceleme. Gazi Eğitim Fakültesi Dergisi, 24(1), 209225.

Sunay, H., Muniroglu, S., Gunduz, N. (2005). The Effect of Physical Education and Sports Teaching Programs in Turkey on Motivation for Physical Activity. Journal of ICHPER, 41(2), 11-15.

Tayga, Y. (1990). Türk spor tarihine genel bakış. T.C. Başbakanlık Gençlik ve Spor Genel Müdürlüğü.

Temiz, C. N., Sivrikaya, A. H. (2021). Beden eğitimi ve spor dersinde karşılaşılan sorunların incelenmesi (Yurt içi ve yurt dışı değerlendirmesi). Avrasya Spor Bilimleri ve Eğitim Dergisi, 3(1), 12-39. DOI: $10.47778 /$ ejsse. 891512

The Australian Council for Health, Physical Education and Recreation, (ACHPER) (2017). Support of the Australian Curriculum: Health and Physical Education.

https://www.achper.org.au/advocacy/national-position-statements/support-for-the-australian-curriculum-healthand-physical-education

Yilmaz, G., Gunduz, N. (2007). Ankara'daki merkez ilköğretim okullarında görevli beden eğitimi ve spor öğretmenlerinin ölçme değerlendirme tekniklerinin uygulanışına ilişkin görüşleri. Spormetre Beden Eğitimi ve Spor Bilimleri Dergisi, 6(3), 103-111.

YÖK (2017). Beden eğitimi ve spor öğretmenliği lisans programı. Retrieved December 5, 2020, from 
https://www.yok.gov.tr/Documents/Kurumsal/egitim_ogretim_dairesi/Yeni-Ogretmen-Yetistirme-LisansProgramlari/Beden_Egitimi_ve_Spor_Ogretmenligi_Lisans_Programi.pdf

YÖK (2020). Yükseköğretim Bilgi Yönetim Sistemi. Retrieved December 5, 2020, from https://istatistik.yok.gov.tr/

Veerendra, K. M. (2020). Recent trends and concepts in physical education and sports- A study. International Journal of Research and Analytical Reviews, 7(1), 148-155.

Wanneberg, P. L. (2018). Gymnastics as a remedy: A study of nineteenth century Swedish medical gymnastics. Athens Journal of Sports, 5(1), 33-52. https://doi.org/10.30958/ajspo.5.1.2 